\title{
Herbalists and their Mode of Health Care Service Delivery in Debre Markos Town, Northwest Ethiopia
}

\author{
Eliyas Taha, Mindaye Shimekit* \\ Department of Social Anthropology, Bahir Dar University, Ethiopia \\ *Corresponding author email: mindayes@gmail.com \\ Received: 01 November 2019 / Revised: 01 December 2019 / Accepted: 07 December 2019 / Published: 10 December 2019
}

\begin{abstract}
The administration of medicinal plants for treating human ailments is an age-old practice. Although several studies have been conducted, most of them focused on documentation of the medicinal plants and herbal knowledge. This study investigated why people use herbal medicine, from what conviction, and explains how the plants are collected, prepared and put to purpose. In order to get deeper information about the issue, both primary and secondary sources are consulted. Observation, semi structured interviews, and key informant interviews were used to collect the primary data.15 herbalists were used as informants to obtain information on knowledge acquisition, plant collection, drug preparation, preservation and administration. The study found that healers got the wisdom of herbal medicine from family; friends or relatives; as gift of God; and religious books. The study also uncovered that people visit herbal healers because of cost, cultural acceptability, easy accessibility, and dissatisfaction with modern medicine. Herbal healers are providing health services for a huge segment of the populations' in spite of several challenges. Dominance of biomedicine, proliferation of quack healers, inheritance problems, absence of support from government authorities, and deforestation stand out as the major challenges for the progress and the very existence of indigenous medicine in general and herbal healers in particular.
\end{abstract}

Keywords: biomedicine, indigenous healers, indigenous medicine, herbal medicine, Debre markos, Ethiopia

\section{Introduction}

Traditional medicine is a combination of knowledge, skills and practices which are depended on theories, beliefs and experiences indigenous to a particular country or social group. It played a great role in diagnosing, preventing and eliminating mental and physical disorders [1]. Before the advent of modern medicine, indigenous medicine was the sole source of remedies for health problems and even after the introduction of modern medicine; they have widely been used by a significant proportion of the population. This knowledge of medicine has been transferred from generation to generation through words of mouth. Herbalists, elders, church scholars and others are the main actors in passing down the knowledge of indigenous medicine. Early medico-religious herbal manuscripts which contain the prescription of several plants have also been serving as sources of knowledge. The use of medicinal plants for various ailments is a long and established practice in Ethiopia. Besides, animal and mineral based medicines, spiritual therapies, and other techniques unique to different regions and cultures are employed to taking care of the wellbeing of the society [2].

Ethiopia is the home of ancient civilizations and varieties of cultures. The people have different strategies to respond to various health problems. More than 1000 plant species have been used and 33 of them believed to be endemic to the country. Most of the time people in Ethiopia are used to visit traditional practitioners and often employed medicines prepared from herbs ${ }^{[3]}$.

Several researches have been conducted on herbalists and use of medicinal plants and related issues in Ethiopia. Few of the studies have been reviewed chronologically in the current study. Alemayehu Letebo [4] conducted an ethno botanical survey of common medicinal plants in southern Ethiopia particularly in

Copyright (C) 2019. The Author(s). Published by AIJR Publisher.

This is an open access article under Creative Commons Attribution-NonCommercial 4.0 International (CC BY-NC 4.0) license, which permits any non-commercial use, distribution, adaptation, and reproduction in any medium, as long as the original work is properly cited. 
Amaro District. Specially, he focused on practices and trends in using medicinal plants, most commonly utilized part of medicinal plants, modes of preparation and threats to medicinal plants.

Tewodros K. and Worku W. [5] accessed indigenous knowledge on medicinal plants that used to treat diseases in some selected districts of Amhara National Regional states by focusing on medicinal plant diversity and knowledge of local healers. On the other hand, Yebirzaf Y. et.al ${ }^{[6]}$ came up with a review on the dynamics of medicinal plants utilization practices in relation to their health and economic role in Ethiopia.

Melaku M. [7] accessed the wisdom of using and treating ailments through medicinal plants in Ethiopia which is located in one of the districts of Oromia National Regional State, Haromaya. In the process the researcher showed how medicinal plants are prepared and administered. Another ethno medicinal survey was made by Dugassa D. et.al ${ }^{[8]}$ in Oromia National Regional state of Ethiopia among the residents of Nekemte town. The survey deals with the collection, preparation and administration of medicinal plants by listing their nomenclature, both scientific and local, in the area under study.

By and large, previous researches were concerned with the history and development of indigenous medicine, and the role of various medicinal plants in treating various ailments in southern, northern and central Ethiopia. Most of the studies were ethno botanical that focused on documenting medicinal plants and knowledge of healers in the community. Most of the plants are documented for further pharmacological testing to prove their healing ability. The researchers of the current study intended to closely look at herbalists' source of knowledge and modality of transfer, the reasons behind people to visit herbal healers, and explains how the plants are collected, prepared and put to purpose. It also assessed the processes of therapeutic methods of herbalists in the study area. Furthermore, challenges that herbalists facing are also addressed.

\section{Description of the Study Area}

Currently, Debre Markos town is the capital of East Gojjam Administrative Zone of Amhara Regional State which is located to the North West part of the Federal Democratic Republic of Ethiopia. It is 300 kilometers away from Addis Ababa, the capital city of Ethiopia, and 265 kilometers away from Bahir Dar which is the capital of Amhara National Regional State. In line with this the town is located between 10 $17^{\prime} 00$ " to $1021^{\prime} 30^{\prime \prime}$ "North latitude and $3742^{\prime} 00^{\prime \prime}$ to $3745^{\prime}$ 30" East longitudes [9]. The town holds an area of 6,160 hectares of land and it has an oval shape. The average temperature of the town is $18.5 \mathrm{c}$ with $1,380 \mathrm{~mm}$ of mean annual rainfall which is directed from north to south. The prospect of the town regarding its expansion is faced with challenges like the existence of hills, swamps, rivers and forests including manmade constraints like illegal settlements and urban- rural conflicts (Figure 1) ${ }^{[10]}$.

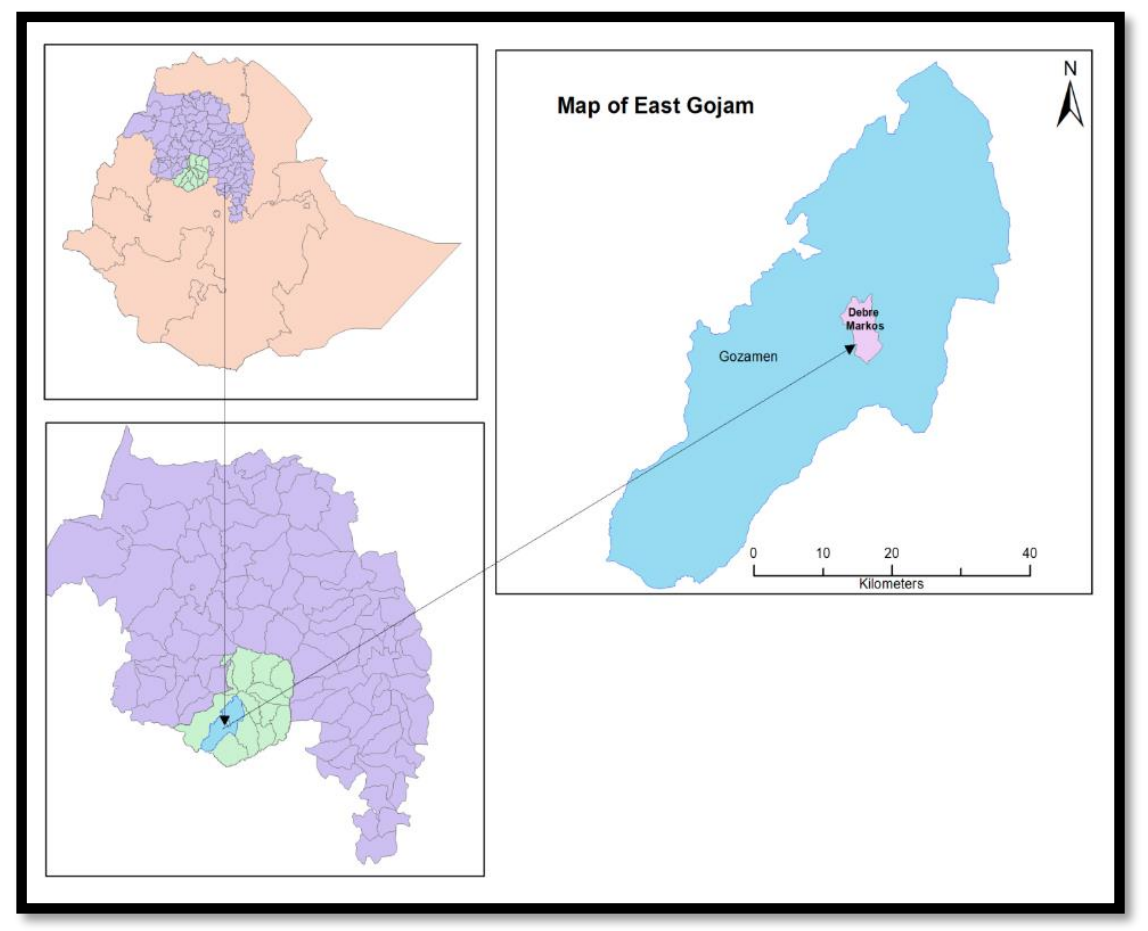

Figure 1: Show the specific location of Debra Markos Town in Amhara National Regional State, Ethiopia. 
Taha et al., Adv. J Social Sci.; Vol. 6 Issue 1, pp: 122-137, 2020

According to the Ethiopian CSA of 2007 the population of Debre Markos town was 62,497 which comprises of $29,921(47.87 \%)$ were males and 32,576 (52.13\%) were females. So that in line with this the age group within 0-15 are 16,325 which accounts $26.14 \%$, between $16-60$ are 42,185 which accounts $67.49 \%$ and age above 60 are 3987 that accounts $6.37 \%$. Besides the town has an average of 2.4 population growth and each household has believed to have an average 3.2 size of population. The people dominantly are Ethiopian Orthodox Church followers and 97\% of the populations are Amharic language speakers and the rest 3\% are Tigrigna, Agaw and Oromo language speakers. The 2013 CSA population projection indicated that the number of the population of the town reach 79,980 of which 38,291 and 41,689 of male and female share of population respectively. In addition, the population projected to be settled within 1214 kilometers square with a density of 65.82 / square kilometer ${ }^{[11]}$.

\section{Methodology}

The participants in this research were 31, which comprised of 15 herbalists, 10 herbal users, 4 officers (2 from town health office and 2 from the regional health bureau), and 2 representatives of traditional healers association of Amhara National Regional State, all of whom purposefully selected based on their experience and knowledge of the issues under study. The researcher used purposive and snowball sampling in determining the size and composition of sample participants. In order to get deeper and richer information about the issue, both primary and secondary sources are consulted. Observation, semi structured interviews, and key informant interviews were used to collect the primary data. Researchers also used photographs as a research tool for documentation and illustration. Secondary data from different published research works that are easily accessible and related online websites were used. 32 medicinal plants that are used by healers are identified with the help of local traditional healers and authenticated specimens of Herbarium of Addis Ababa University/Ethiopia. With the support of professionals from pharmacology department, the collected plant specimens were identified using best possible taxonomic literatures of; Edwards et al. [12] Tadesse $\mathrm{M}^{[13]}$ and Hedberg et al. ${ }^{[14]}$ and Yemane B. ${ }^{15]}$. Survey method was also used to support qualitative data gathered through key informant interview and observation. 15 herbal healers and specific documents from the traditional healers association of Amhara National Regional State were also used to obtain information on herbal medicine administration, modality of transfer, plant parts used and the condition of plant or plant part used. The data, which were largely qualitative, passed through processes like transcribing, immersion, coding, sorting, categorizing, interpreting and finally representation. The quantitative data were tabulated, analyzed and presented appropriately. The medicinal plants are also tabulated and presented by the ailment treated, parts used, preparation and administration.

\section{Results and Discussions}

In Amhara National Regional State, indigenous medicines are being practiced by a variety of individuals. It comprises herbalists, bone setters, spirit-related healers, and birth attendants. According to informants from the region, 181 legally registered indigenous healers are providing health care services for the local community. Although a number of spiritual healers and faith healing practices are operating, the regional health bureau doesn't recognize them. It only recognizes healers who provide health care services using plants, minerals, animal products and treatments of manual techniques. Despite differences on the sources of indigenous medicine, healers use plants, minerals, and animals including insects for the treatment of several ailments. Plants are used in a grand scale in the study area while animals and minerals are utilized to a lesser extent.

\subsection{Herbalists: Sources of Knowledge and Modality of transfer}

The dynamic and complex interaction of human beings with their surrounding environment has enabled them to develop remedies for pressing health problems. These remedies are derived from plants, animals and mineral substances. People have developed this medical knowledge through day to day experience. Early ancestors wrote the medicinal plant genealogy, preparations, prescriptions and administrations. These 
hand written medico-religious manuscripts are termed as Etse debdabe (lit. letters of herbs), written by debteras who were among the few scholars trained in the literature of the church (could read and write Geez). These medical manuscripts have been kept as esoteric which cannot be taught to the general public.

Based on the data gathered from several herbalists, healers received the wisdom of herbal medicine from their father; friends or relatives (who have meticulous understanding of the medicinal plants kingdom thought to have medicinal values); gift of God; and religious books. Above all, church education is believed to be the fundamental source of indigenous medicine in general and herbal medicine in particular. Healers without knowledge of geez would not have a deeper knowledge and understanding on the flora and fauna of the surrounding areas with their medicinal uses, because most of the knowledge related to medicinal plant preparation, prescription, preservation and administration were written in geez by early church scholars.

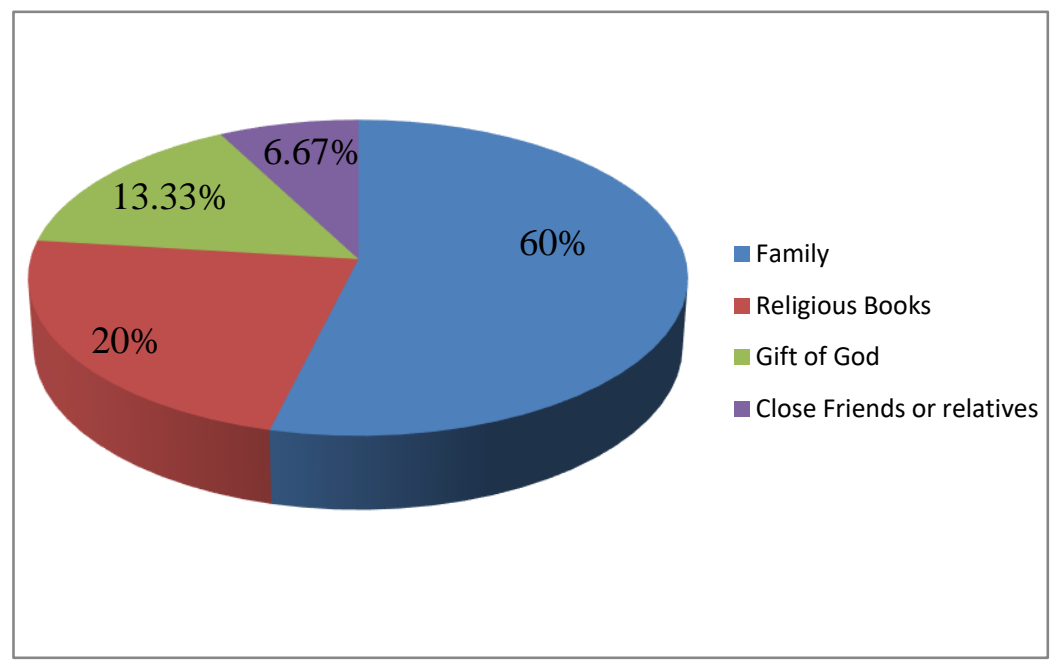

Figure 2: Major sources of Healing Knowledge of Herbalists

Concerning the source of knowledge, the highest and commonly cited source of healing is family which accounts $9(60 \%)$ of participant healers. Here, family as a source of indigenous medical knowledge followed, in decreasing order, by religious books that covers $3(20.66 \%)$, gift of God which accounts $2(13.33 \%)$ and finally from close friends or relatives that accounts $1(6.67 \%)$. The age ranges of practitioners that are participated in the process are between 37 to 65 years (see figure. 2).

Herbalists have also become familiar with knowledge of herbal medicine from their father being a longstanding apprentice. One herbalist expressed that his father used to practice herbal medicine for a long period. As the elder son of the family, he had been assisting his father in the collection and preparation of medicinal plants. He informed that "my father used to order me to collect medicinal plants early in the morning without discharging my urine." The information related to indigenous knowledge is largely transferred from generation to generation through words of mouth, being an apprentice or as parchments (manuscripts being written on animals hide) and these parchments are largely found in the hands of few traditional healers. Thus, healers refer to these ancient key texts for their theoretical framework. Foreign scholars who have made extensive research on Ethiopian traditional medical knowledge indicate that acquiring and mastering traditional medicinal knowledge requires an excellent mind caliber and an extended period of training roaming from place to place; possessing strong linguistic, moral and religious qualities. As a testimony to this, Frew B. ${ }^{[16]}$ states that knowledge of traditional medicines is transferred orally from generation to generations among family members, especially to their sons, often with considerable secrecy.

\subsection{Medicinal Plants Collections, Preparations, Storage and Administrations}

Plants of different nature are utilized for medicine, food, shelter, and clothing. Trees, shrubs, climbers, herbs are among the several categories of plants used for fulfilling basic human needs. People also make 
use of plants in treating various animal diseases. To utilize plants for human medicine, stringent procedures are followed beginning from collection to preparation, preservation and administration.

\subsubsection{Medicinal Plants: Collections}

The growth and collection of plants differ based on seasons and state of the atmosphere. Most of the plants are collected in summer and others in winter. There are perennial plants that last for more than two growing seasons. There are also ephemeral plants that are available at a certain season and disappear in another. To avert this risk and as an insurance of poor seasons, herbalists gather plants in their growing season and prepare in a way they can stay for long period of time without losing their medicinal efficacy. In expressing the medicinal roles of plants, informant stated that "God created human beings with maladies and appropriate remedies, and these remedies are found in a forest; that is why forests are called the living pharmacy for indigenous people." Similarly, Tilahun T. and Moa M. ${ }^{[17]}$ indicated that since prehistoric times plant kingdom has been used for medicine and the application of herbal therapy is the first healing method known to human being. The great majority of herbalists are well aware of the seasons when the medicinal plants ripe and ready for gathering. Informants described that a significant number of medicinal plants are gathered from September to December, for the reason that in the rainy season from June to end of August, rivers in Ethiopia overflow and cover the herbs found on the bank of the river thereby decreasing their medicinal properties. Besides, some medicinal plants only grow in a relatively moist soil.

Herbalists have also the knowledge of the place or locality of plants which have high medicinal value. Occasionally, herbalists ask colleagues for the whereabouts of the plants, and seldom referring to the ancient key texts or manuscripts. Semien Mountains, the gorge of Nile, Abay, banks of the rivers are some of the areas where medicinal plants are largely available. Rarely, they cross regional and international boundaries travelling as far as Benishangul Gumuz National Regional State and Sudan, respectively. Virtually all herbalists also cultivate medicinal plants in their home gardens. In this regard, nech sbinkurt (Garlic), tikur åmud (Black Cumin), zingibel (ginger) are worth mentioning.

In the process of collecting medicinal plants, there are different ritual procedures such as sprinkling holy water on the plants and the surrounding areas and slaughtering chicken and scattering out the blood before removing the plant. In addition, the collector might also be obliged to refrain from any sexual activity prior to collection, never to see a corpse/dead body of human; not spewing mucous around, never greeting a woman who has given birth recently. It is likely that these and other rituals are passed down from ancestors or forefathers. It is also highly recommendable to dig and collect medicinal plants on Wednesday and Friday, because Jews betrayed Jesus on Wednesday; Friday was a day of the crucifixion. On these days, it is presumed that the collector would own the power and energy of Satan to dig up the plants. The herbalists are also expected to temporarily remove their cross so as to possess the power of the devil in cutting the plants. Almost all of the herbalists unanimously agreed that plants are collected at dawn or in the early morning without taking a meal and passing urine. Contrary to this Boadu A. and Asase A ${ }^{18]}$ indicated that herbalists in southern Ghana are flexible and collect medicinal plants when they are needed, especially in the case of emergency. Besides, herbalists are engaged in harvesting medicinal plants in both dry and wet seasons of the year.

To protect one from the malevolent spirits, medicinal plants are dug up and cut by instruments made from horn and olive plant that are believed to prevent and ward off evil spirit. Some herbalists express that the issue of collecting and digging out medicinal plants with horn made instruments and olive plants are not rational and is a deliberate distortion intending to make things complicated, secret and difficult to understand. They added that whatever the digging instruments are used, plants would not lose their medicinal properties. It is also believed that the burned smoke of Olive tree is vital for exorcising evil spirits. After the plant is cut or dug out, it should not be placed on bare ground rather it has to be put in a $\mathrm{bag} / \mathrm{basket}$ prepared for this purpose. In the study area, it is widely believed that putting the plants on bare surface while collecting would lessen their medicinal effectiveness. 
Herbalists and their Mode of Health Care Service Delivery in Debre Markos Town, Northwest Ethiopia

Plants should not also be collected from streets and dirty places. They need to be collected at appropriate time without being dry and wilt. Furthermore, plants should not be grown with manmade fertilizers, and chemicals should not be sprinkled on to get rid of germs and weeds.

\subsubsection{Medicinal Plants: Preparations and Preservation}

Obviously, the collected plants have to be washed and cleaned because they might hold dirt that is detrimental to the user's health. It is not also desirable to expose plants to sunlight; rather they need to be dried in windy places because the light of the sun would change the original color of the plant causing plants to lose their medicinal values. For medicine preparation, unadulterated materials or instruments that are independent of other purposes should be prepared and used.

The art of preparing herbal medicine differs from herbalists to herbalists and is also contingent on the types of health maladies. The dried plants have to be chopped, crushed, pounded and changed into powder form for long time preservation, and finally have to be packed in plastic bottles or jars. Plants can be used in fresh form for certain diseases. The preparation might be in flour/powder, liquid, ointment or raw form. They can also be prepared combining or mixing different herbs or the different parts of a plant or several plants. Moreover, herbalists prefer to use medicinal plants/parts of plants in fresh form because the probability of losing their healing strength when fresh is low.

In the study area, herbalists use the roots, stem, barks, flowers, fruits, and leaves of the medicinal plant. Besides, there has been a trend of mixing prepared herbs with honey and butter to make bitter and unpleasant herbs tasty and palatable. Medicinal plants are also sometimes given in conjunction with holy water or tsebel. In line with this, Jyoti P. et.al [19] showed that Ayurveda, a well-known and established traditional herbal medical system of India, involves the use of different parts of a plant like seeds, roots, berries, leaves, barks and flowers for medicinal purposes. In addition, parts of the medicinal plants also used combined with plant and animal products, minerals and other forms of substances.

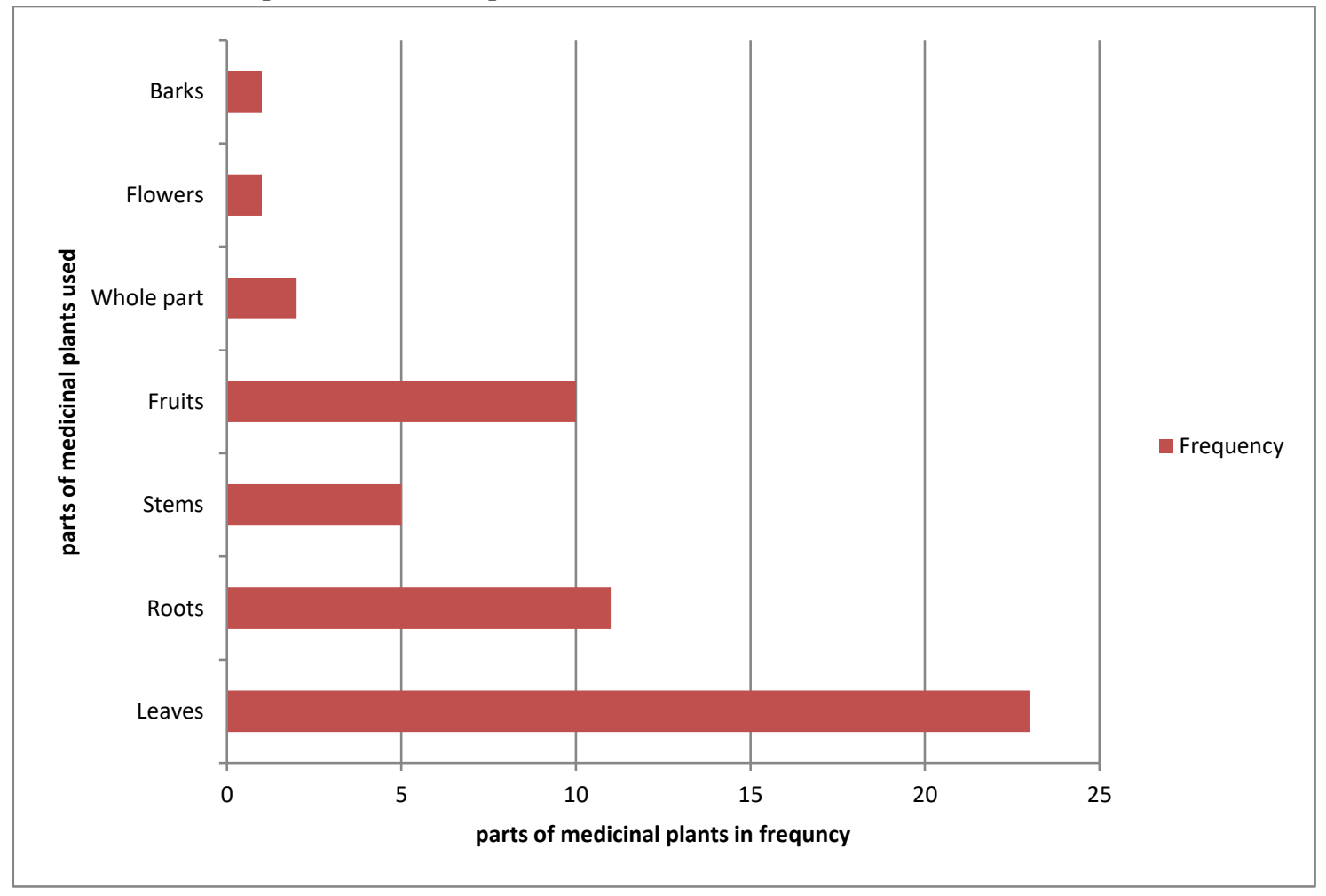

Figure 3: Parts of medicinal plants used for medicinal drugs and their frequency

Among 53 plant parts, leaf took the highest percentage which accounts 23 (43.4\%) followed by root 14 (20.8\%), fruit $10(19 \%)$, stem $5(9.4 \%)$, whole part $2(3.8 \%)$, bark $1(1.9 \%)$ and flower $1(1.9 \%)$ (See figure 3). Besides, these plant parts can be prepared in the form of juice, powder or raw form. 
Here medicinal plants need to be dried, pounded and should be packed in bottle or jar for further preservation. In this case, there is no standard ways of medicinal plants preparation, rather the process of preparation differs from practitioner to practitioners. In relation to this Boadu A. and Asose A. ${ }^{[18]}$. affirmed that communities in southern Ghana prepared harvested herbal materials in the form of decoctions and infusions. Even if these forms are widely reported in the given communities, the study indicated that there is no standard form of herbal material preparation. As a result, a variety of methods are employed to prepare herbal medicines that differ from one healer to the other.

\subsubsection{Medicinal Drugs: Storage and Administrations}

In storing medicinal drugs, there are herbalists with well organized room. They have good ways of sorting, arranging and storing medicinal drugs like modern pharmacy does. As the researcher of the current study observed in the field, the medicines are preserved on the shelf in plastic bottles/jars. Medicinal drugs are stored in clean areas; moreover, each medicine and other additives that are kept on shelf are all recorded with their respective code number, name, manufacture and expiry dates. Herbal treatment is the most common therapeutic method used in the study area. The recipes are usually secret and are part of the knowledge that the healer will pass on to his apprentice. Multifaceted treatment methods are used in the application of herbal medications. Most of the time, herbalists refrain from providing herbal medicine in oral form for aged people, children, pregnant and breast-feeding women. Only external administration of the medicine is largely prescribed. Sometimes, the patients are required to take the medicinal drugs on a regular basis coming to healer's clinic or at their home. The latter option is largely applicable to patients coming from distant areas. According to the information obtained from herbalists, the expiry dates of the medicine are known from their prolonged trials/experience. The medicinal plants that stay for a long period (approximately eight months) without being utilized would lose medicinal values.

As far as the timing of medicine intake is concerned, medicinal drugs are taken at night, early morning, noon time and are recommended to be taken after or before a meal. In contrast to modern medicine, most of the drugs are recommended to be taken before a meal, which is considered to be important for the drug to directly attack the disease-causing agents. Some others are taken whenever the person/patient feels the pain. The healers should also clearly know the history of the patient if there are chronic diseases such as blood pressure, diabetes, cardiovascular diseases, and HIV/AIDS are identified by modern medical practitioners. Thus, the healer refers the patients to get checked for such diseases before prescribing herbal medicines. To avoid other health complications, the indigenous medicines are not given in combination with the modern medicine.

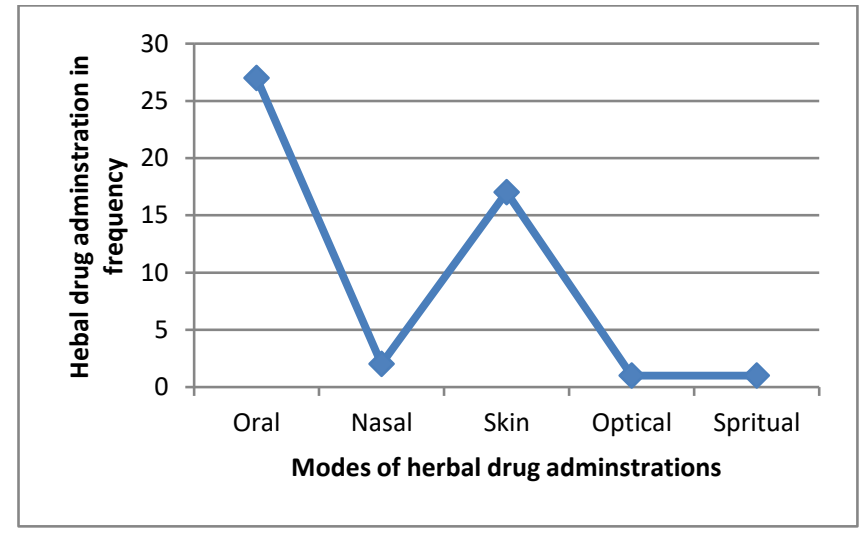

Figure 4: Mode of herbal medicine drug administration, prescription, to patients by traditional healers

As far as the survey on herbal medicine drug administration is concerned, more than half of the herbal drugs, $27(56.3 \%)$, is administered to sick individuals orally and consecutively followed by skin 17 (35.4\%), nasal $2(4.2 \%)$, optical $2(4.2 \%)$ and spiritual $1(4.2 \%)$. Here, especially those traditional medicinal drugs taken or administered orally are often disapproved by modern health professionals because of dosage and hygiene related problems (see Figure 4). 
Herbalists and their Mode of Health Care Service Delivery in Debre Markos Town, Northwest Ethiopia

Based on the severity of the disease, the prescribed medicine might last for different durations, like for a day, three days, seven days, two weeks or months. For injuries like wounds, the patient takes the medicine until he / she gets cured. According to informants, the dosages of the medicines are determined by the age, sex and physical statuses of the patient. Most herbalists determine the dosage of a certain medicine using spoon, cup, handful, etc. One of the interviewed informants remarked that for children the dosage amount is simply half of the adults. Here we have a table (Table 1) that show medicinal plants with their scientific and local names, parts of plant used, ailments treated with their preparation and administrations.

Table 1: Medicinal Plants used to treat human ailments with brief explanations for their preparations and administrations in Debre Markos Town, Northwest Ethiopia

\begin{tabular}{|c|c|c|c|c|c|c|}
\hline $\begin{array}{l}\text { No } \\
\text {. }\end{array}$ & $\begin{array}{l}\text { Species } \\
\text { name }\end{array}$ & $\begin{array}{l}\text { Local } \\
\text { name }\end{array}$ & $\begin{array}{l}\text { Parts } \\
\text { used }\end{array}$ & Ailments treated & Preparations and administration & Remarks \\
\hline \multirow[t]{2}{*}{1.} & \multirow{2}{*}{$\begin{array}{l}\text { Euclea } \\
\text { racemosa } \\
L .\end{array}$} & Dedeho & roots & tooth ache & $\begin{array}{l}\text { Chewing the barks of the root and } \\
\text { holding in the mouth }\end{array}$ & \multirow[t]{2}{*}{$\begin{array}{l}\text { Has strong stem that could } \\
\text { not be easily broken. }\end{array}$} \\
\hline & & & leaves & $\begin{array}{l}\text { control bleeding } \\
\text { scabies (skin } \\
\text { blister), eczema }\end{array}$ & $\begin{array}{l}\text { leaves grounded with water } \\
\text { applied on the affected parts of } \\
\text { the body }\end{array}$ & \\
\hline 2. & $\begin{array}{l}\text { Verbascum } \\
\text { sinaiticum }\end{array}$ & Ketetina & $\begin{array}{l}\text { whole } \\
\text { part }\end{array}$ & $\begin{array}{l}\text { diarrhea } \\
\text { (cholera), } \\
\text { stomachache/abd } \\
\text { ominal pain, } \\
\text { nausea }\end{array}$ & $\begin{array}{l}\text { pounding whole part of the plant } \\
\text { and soaking with water, milk or } \\
\text { honey and taking it orally (in drink } \\
\text { form) }\end{array}$ & $\begin{array}{l}\text { Grow naturally in high } \\
\text { altitude, most commonly in } \\
\text { stony area }\end{array}$ \\
\hline 3. & Lens esculenta & Misr & fruits & $\begin{array}{l}\text { erectile } \\
\text { dysfunction }\end{array}$ & $\begin{array}{l}\text { boiling the fruits in a cooking pan } \\
\text { mixing with black cumin and pure } \\
\text { honey, and taking it orally for } \\
\text { seven consecutive days. It can also } \\
\text { be prepared in stew from and } \\
\text { eating with bread or injera }\end{array}$ & \\
\hline 4. & $\begin{array}{l}\text { Adbathoda } \\
\text { schimperiana }\end{array}$ & Smiza & leaves & $\begin{array}{l}\text { mitch (fever), } \\
\text { influenza }\end{array}$ & $\begin{array}{l}\text { boiling the leaves in a cooking pot } \\
\text { and inhaling the steam at night }\end{array}$ & $\begin{array}{l}\text { The root of the plant is } \\
\text { used for children who have } \\
\text { anxious feeling and also } \\
\text { serves as prevention and } \\
\text { exorcism of evil spirit. The } \\
\text { root is tied on neck of a } \\
\text { child. The leaves is } \\
\text { pounded and dabbed on } \\
\text { the head of the child to get } \\
\text { rid of evil eye. It is also } \\
\text { used to withstand the } \\
\text { malicious action of } \\
\text { witchcraft/sorcery. } \\
\text { Equivalent to Dama Kase } \\
\text { (Ocimum lamiifolium) for the } \\
\text { treatment of mitch. }\end{array}$ \\
\hline 5. & $\begin{array}{l}\text { Aloe } \\
\text { pulcherrima }\end{array}$ & $\begin{array}{l}\text { Eret(Sete } \\
\text { eret) }\end{array}$ & stem & $\begin{array}{l}\text { dermatological } \\
\text { diseases }\end{array}$ & $\begin{array}{l}\text { Chopping and squeezing out the } \\
\text { stem to extract the latex and } \\
\text { rubbing the milky white liquid on } \\
\text { the affected part of the body }\end{array}$ & $\begin{array}{l}\text { There are eighty different } \\
\text { species of the plant } \\
\text { worldwide. Of these, sixty } \\
\text { eight types exist in } \\
\text { Ethiopia. Herbalists classify } \\
\text { it as male and female. The } \\
\text { female is used for the } \\
\text { mentioned ailments. The } \\
\text { remnants of the extracted } \\
\text { latex are also used for } \\
\text { cosmetics and hair } \\
\text { protection. It also served as } \\
\text { a candle. }\end{array}$ \\
\hline
\end{tabular}


Taha et al., Adv. J Social Sci.; Vol. 6 Issue 1, pp: 122-137, 2020

\begin{tabular}{|c|c|c|c|c|c|c|}
\hline & & & & & & $\begin{array}{l}\text { The male on has no } \\
\text { significance for medicinal } \\
\text { purpose. It has also a very } \\
\text { unpleasant odor. }\end{array}$ \\
\hline & & & & $\begin{array}{l}\text { heart disease, } \\
\text { diabetes, } \\
\text { headache, blood } \\
\text { pressure }\end{array}$ & $\begin{array}{l}\text { Administering the extracted milky } \\
\text { juice of the plant orally }\end{array}$ & \\
\hline & & & & $\begin{array}{l}\text { Eye } \\
\text { sore/infection } \\
\text { (Trachoma) }\end{array}$ & $\begin{array}{l}\text { Rubbing the eyelid and eyelash } \\
\text { using the extracted juices }\end{array}$ & \\
\hline 6. & $\begin{array}{l}\text { Carissa } \\
\text { spinarum L. }\end{array}$ & Agam & $\begin{array}{l}\text { fruits, } \\
\text { leaves, } \\
\text { roots }\end{array}$ & stomachache & $\begin{array}{l}\text { Pounding the fresh fruits and } \\
\text { leaves of the plant together and } \\
\text { taking it orally }\end{array}$ & \\
\hline \multirow[t]{2}{*}{7.} & \multirow[t]{2}{*}{$\begin{array}{l}\text { Plumbago } \\
\text { zeylancium }\end{array}$} & \multirow[t]{2}{*}{ Amira } & leaves & $\begin{array}{l}\text { skin fungus, gout, } \\
\text { rheumatism }\end{array}$ & $\begin{array}{l}\text { Chopping and boiling the leaves } \\
\text { like a cabbage in a cooking dish, } \\
\text { eating with butter for three } \\
\text { consecutive days }\end{array}$ & \\
\hline & & & roots & Coughing & $\begin{array}{l}\text { Grinding the roots, infusing with } \\
\text { honey and taking it orally }\end{array}$ & \\
\hline 8. & Sida massaica & Chifrig & $\begin{array}{l}\text { roots, } \\
\text { leaves }\end{array}$ & $\begin{array}{l}\text { dermatological } \\
\text { diseases (bleeding } \\
\text { scabies), wounds } \\
\text { on legs }\end{array}$ & $\begin{array}{l}\text { chopping, and pounding the } \\
\text { fresh/dried roots and leaves of the } \\
\text { plant together, infusing with honey } \\
\text { can be applied of the affected part }\end{array}$ & \\
\hline 9. & Olea africana & Weyra & $\begin{array}{l}\text { leaves, } \\
\text { fruits }\end{array}$ & nerve diseases & $\begin{array}{l}\text { Collecting, cleaning/washing the } \\
\text { plant and eating in fresh/raw form }\end{array}$ & \\
\hline \multirow[t]{2}{*}{10.} & \multirow[t]{2}{*}{ Unknown } & \multirow[t]{2}{*}{$\begin{array}{l}\text { Muatis/s } \\
b\end{array}$} & \multirow[t]{2}{*}{$\begin{array}{l}\text { flowers, } \\
\text { leaves }\end{array}$} & $\begin{array}{l}\text { dermatological } \\
\text { diseases (like } \\
\text { scabies, psoriasis) }\end{array}$ & $\begin{array}{l}\text { Drying and pounding the flower } \\
\text { and the leaves together and } \\
\text { applying on the affected parts of } \\
\text { the body }\end{array}$ & $\begin{array}{l}\text { Spiritually, it is important } \\
\text { to take away the wealth of a } \\
\text { certain person. the term } \\
\text { literally means 'bring all } \\
\text { without any traces' }\end{array}$ \\
\hline & & & & Tonsils & Drinking it orally & \\
\hline 11. & $\begin{array}{l}\text { Pittosporum } \\
\text { virdifolium }\end{array}$ & $\begin{array}{l}\text { Dingay } \\
\text { seber }\end{array}$ & leaves & $\begin{array}{l}\text { backache, joint } \\
\text { dislocation, } \\
\text { muscular injuries }\end{array}$ & $\begin{array}{l}\text { mixing the leaves with honey and } \\
\text { bandaging the affected area with } \\
\text { cloth strip }\end{array}$ & $\begin{array}{l}\text { Naturally grow in desert } \\
\text { areas }\end{array}$ \\
\hline \multirow[t]{2}{*}{12.} & \multirow[t]{2}{*}{$\begin{array}{l}\text { Withania } \\
\text { somnifera }\end{array}$} & \multirow[t]{2}{*}{ Grewa } & \multirow[t]{2}{*}{$\begin{array}{l}\text { roots, } \\
\text { leaves }\end{array}$} & Wounds & $\begin{array}{l}\text { Grinding the roots and leaves of } \\
\text { the plant infusing with honey, and } \\
\text { applying on the affected parts of } \\
\text { the body. }\end{array}$ & \multirow{2}{*}{$\begin{array}{l}\text { It is also used for the } \\
\text { treatment of evil eye. } \\
\text { Used for general well being. } \\
\text { It is presumed to treat all } \\
\text { kinds of ailments. } \\
\text { The known local genre } \\
\text { related to this plant is: } \\
\text { While gzewa is growing in } \\
\text { your front yard, why your } \\
\text { child is dying of illnesses? }\end{array}$} \\
\hline & & & & diarrhea, nausea & Has to be taken orally & \\
\hline \multirow[t]{2}{*}{13.} & \multirow[t]{2}{*}{$\begin{array}{l}\text { Kalanchoe } \\
\text { lanceolata }\end{array}$} & \multirow[t]{2}{*}{$\begin{array}{l}\text { Andahul } \\
a\end{array}$} & \multirow[t]{2}{*}{$\begin{array}{l}\text { roots, } \\
\text { leaves, } \\
\text { stem }\end{array}$} & Swelling & $\begin{array}{l}\text { mildly warming the leaves, stem } \\
\text { and roots of the plant on fire, } \\
\text { rubbing it on the swelled parts of } \\
\text { the body. }\end{array}$ & \\
\hline & & & & hemorrhoid & $\begin{array}{l}\text { Pounding the root, rubbing on the } \\
\text { diseased part. }\end{array}$ & \\
\hline 14. & $\begin{array}{l}\text { Nicotiana } \\
\text { tabacum L. }\end{array}$ & Tinbaho & leaves & $\begin{array}{l}\text { dermatological } \\
\text { disease }\end{array}$ & $\begin{array}{l}\text { Rubbing on the diseased parts of } \\
\text { the body by drying, grinding and } \\
\text { using it in powder } \\
\text { form or in a raw form }\end{array}$ & $\begin{array}{l}\text { Can also be used for } \\
\text { making evil spirit disappear }\end{array}$ \\
\hline \multirow[t]{2}{*}{15.} & \multirow[t]{2}{*}{$\begin{array}{l}\text { Milliya } \\
\text { azadrica }\end{array}$} & \multirow[t]{2}{*}{ Neem } & \multirow[t]{2}{*}{ leaves } & $\begin{array}{l}\text { dermatological } \\
\text { disease }\end{array}$ & $\begin{array}{l}\text { Kneading the leaves of the plant on } \\
\text { the affected part of the body }\end{array}$ & \\
\hline & & & & Malaria & $\begin{array}{l}\text { Striking the leaves hard, mixing } \\
\text { with water, taking it orally }\end{array}$ & \\
\hline
\end{tabular}


Herbalists and their Mode of Health Care Service Delivery in Debre Markos Town, Northwest Ethiopia

\begin{tabular}{|c|c|c|c|c|c|c|}
\hline 16. & $\begin{array}{l}\text { Jasminum } \\
\text { grandiflorum } \\
\text { L. }\end{array}$ & Tembelel & $\begin{array}{l}\text { whole } \\
\text { parts }\end{array}$ & $\begin{array}{l}\text { wounds on scalp, } \\
\text { wart }\end{array}$ & $\begin{array}{l}\text { Pounding whole parts of the plant } \\
\text { infusing with honey and butter, } \\
\text { applying it on the scalp }\end{array}$ & \\
\hline \multirow[t]{2}{*}{17.} & \multirow[t]{2}{*}{$\begin{array}{l}\text { Calpurnia } \\
\text { aurea }\end{array}$} & \multirow[t]{2}{*}{ Zigta } & \multirow[t]{2}{*}{$\begin{array}{l}\text { leaves, } \\
\text { fruits }\end{array}$} & $\begin{array}{l}\text { stomachache, } \\
\text { diarrhea, }\end{array}$ & $\begin{array}{l}\text { Pounding the fresh leaves and } \\
\text { fruits, extracting the juices, and } \\
\text { drinking it orally. }\end{array}$ & \\
\hline & & & & Wound & $\begin{array}{l}\text { Massaging the pounded leaves on } \\
\text { the diseased part of the body }\end{array}$ & \\
\hline \multirow[t]{2}{*}{18.} & \multirow[t]{2}{*}{$\begin{array}{l}\text { Syzygium } \\
\text { guineese }\end{array}$} & \multirow[t]{2}{*}{ Dokma } & \multirow[t]{2}{*}{$\begin{array}{l}\text { fruits, } \\
\text { leaves }\end{array}$} & $\begin{array}{l}\text { swelling on legs } \\
\text { and face (because } \\
\text { of food lose) }\end{array}$ & $\begin{array}{l}\text { Eating while the plant is not fully } \\
\text { developed or unripe }\end{array}$ & \\
\hline & & & & Weight lose & $\begin{array}{l}\text { Eating the mentioned part of the } \\
\text { plant. It is presumed to be an } \\
\text { important source of multi vitamin. }\end{array}$ & \\
\hline 19. & $\begin{array}{l}\text { Ocimum } \\
\text { lamifolium }\end{array}$ & Besobla & leaves & $\begin{array}{l}\text { anxiety, heart } \\
\text { disease }\end{array}$ & $\begin{array}{l}\text { preparing it in the form of tea } \\
\text { together with tej sar (Cymbopogon } \\
\text { citratus) }\end{array}$ & \\
\hline \multirow[t]{2}{*}{20.} & \multirow[t]{2}{*}{$\begin{array}{l}\text { Achyranthes } \\
\text { aspera }\end{array}$} & \multirow[t]{2}{*}{ Telenj } & \multirow[t]{2}{*}{ leaves } & $\begin{array}{l}\text { blood pressure, } \\
\text { diabetes, }\end{array}$ & $\begin{array}{l}\text { Eating the plant like khat together } \\
\text { with honey, a powerful energy } \\
\text { giver. }\end{array}$ & \\
\hline & & & & Wounds & $\begin{array}{l}\text { Pounding and rubbing on the } \\
\text { wound }\end{array}$ & \\
\hline \multirow[t]{2}{*}{21.} & \multirow[t]{2}{*}{$\begin{array}{l}\text { Clerodendrumy } \\
\text { ricoides(Hochst } \\
\text {.) }\end{array}$} & \multirow[t]{2}{*}{ Misirich } & \multirow[t]{2}{*}{ leaves } & Asthma & $\begin{array}{l}\text { Crushing and pounding the leaves } \\
\text { and taking it orally together with } \\
\text { pure honey }\end{array}$ & \multirow[t]{2}{*}{$\begin{array}{l}\text { Used for any kind of } \\
\text { illnesses caused by evil } \\
\text { sprits }\end{array}$} \\
\hline & & & & Swell & $\begin{array}{l}\text { Kneading the swelled parts of the } \\
\text { body with the leaves }\end{array}$ & \\
\hline \multirow[t]{2}{*}{22.} & \multirow[t]{2}{*}{$\begin{array}{l}\text { Cordia } \\
\text { africana }\end{array}$} & \multirow[t]{2}{*}{ Wanza } & roots, & liver disease, & $\begin{array}{l}\text { Drying, grinding and mixing it with } \\
\text { water and taking it orally }\end{array}$ & \\
\hline & & & $\begin{array}{l}\text { barks, } \\
\text { fruits }\end{array}$ & intestinal worms & $\begin{array}{l}\text { Drying, grinding and mixing it with } \\
\text { water and taking it orally }\end{array}$ & \\
\hline 23. & $\begin{array}{l}\text { Trigonella } \\
\text { foenum- } \\
\text { graecum } L .\end{array}$ & Abish & fruits & $\begin{array}{l}\text { liver and kidney } \\
\text { cleaning }\end{array}$ & $\begin{array}{l}\text { Drying, grinding and making it in } \\
\text { flour form. Drinking it with water } \\
\text { every morning }\end{array}$ & \\
\hline 24. & $\begin{array}{l}\text { Malva } \\
\text { verticillata } \\
\text { L. }\end{array}$ & $\begin{array}{l}\text { Lut/ya } \\
\text { wusha } \\
\text { milas/yeb } \\
\text { ere milas }\end{array}$ & $\begin{array}{l}\text { leaves, } \\
\text { roots }\end{array}$ & $\begin{array}{l}\text { runny nose, nasal } \\
\text { wounds and } \\
\text { wounds on lips }\end{array}$ & $\begin{array}{l}\text { Inserting the fresh leaves of the } \\
\text { plant in the nasal cavity of the } \\
\text { patient to arrest bleeding nose. It } \\
\text { also plays a bigger role for lip and } \\
\text { nose wounds. }\end{array}$ & \\
\hline 25. & $\begin{array}{l}\text { Ruta } \\
\text { chalepensis }\end{array}$ & Tenadam & leaves & For any ailments & $\begin{array}{l}\text { Mixing it with all plants grinding it } \\
\text { with Sodium chloride }\end{array}$ & \\
\hline 26. & Unknown & Amken & fruits & Tapeworm & $\begin{array}{l}\text { Pounding the fruits and mixing it } \\
\text { with nug (Guizota abyssinica)and } \\
\text { taking it orally }\end{array}$ & \\
\hline \multirow[t]{2}{*}{27.} & \multirow[t]{2}{*}{$\begin{array}{l}\text { Rumex } \\
\text { nervosus }\end{array}$} & \multirow[t]{2}{*}{ Embacho } & \multirow[t]{2}{*}{$\begin{array}{l}\text { stem, } \\
\text { leaves }\end{array}$} & gastritis, & $\begin{array}{l}\text { Eating the stem, leaves in a } \\
\text { raw/fresh form }\end{array}$ & \\
\hline & & & & $\begin{array}{l}\text { eye infection, } \\
\text { control bleeding }\end{array}$ & $\begin{array}{l}\text { Pounding the stem and leaves } \\
\text { together and rubbing it on the } \\
\text { affected part. }\end{array}$ & \\
\hline \multirow[t]{2}{*}{28.} & \multirow[t]{2}{*}{$\begin{array}{l}\text { Cucumis } \\
\text { ficifolius }\end{array}$} & \multirow[t]{2}{*}{$\begin{array}{l}\text { Midr } \\
\text { Embuay }\end{array}$} & roots & $\begin{array}{l}\text { Abdominal } \\
\text { problems, } \\
\text { rheumatism }\end{array}$ & $\begin{array}{l}\text { Chopping and pounding the roots } \\
\text { and taking it orally }\end{array}$ & \\
\hline & & & $\begin{array}{l}\text { leaves, } \\
\text { fruits }\end{array}$ & Wounds & $\begin{array}{l}\text { Leaves and fruits of the plant are } \\
\text { pounded together and taken orally }\end{array}$ & \\
\hline 29. & $\begin{array}{l}\text { Cucumis } \\
\text { dipsaceus }\end{array}$ & $\begin{array}{l}\text { Amora } \\
\text { keleb }\end{array}$ & fruit & $\begin{array}{l}\text { Dermatological } \\
\text { disease }\end{array}$ & $\begin{array}{l}\text { The fruits are pounded and rubbed } \\
\text { on the affected part }\end{array}$ & \\
\hline 30. & $\begin{array}{l}\text { Dodonaea } \\
\text { angustifolia }\end{array}$ & kitkita & leaves & Dandruff & $\begin{array}{l}\text { Leaves are pounded and applied on } \\
\text { scalp }\end{array}$ & $\begin{array}{l}\text { The pounded leaves are } \\
\text { also used to get rid of } \\
\text { parasites from animal skin }\end{array}$ \\
\hline
\end{tabular}


Taha et al., Adv. J Social Sci.; Vol. 6 Issue 1, pp: 122-137, 2020

\begin{tabular}{|l|l|l|l|l|l|l|}
\hline 31. & $\begin{array}{l}\text { Sansevieria } \\
\text { ebrenbergii }\end{array}$ & $\begin{array}{l}\text { Wende } \\
\text { chiret }\end{array}$ & Roots & $\begin{array}{l}\text { Premature } \\
\text { ejaculation }\end{array}$ & $\begin{array}{l}\text { The root is pounded and infused } \\
\text { with honey and taken orally }\end{array}$ & \\
\cline { 4 - 6 } & stem & Ear problem & $\begin{array}{l}\text { Heating the stem on fire and the } \\
\text { fluid of the broken stem applied on } \\
\text { the infected ear }\end{array}$ & $\begin{array}{l}\text { Grinding the stem and taking it } \\
\text { orally }\end{array}$ & $\begin{array}{l}\text { Snake bite } \\
\text { (venom) }\end{array}$ \\
\hline 32. & $\begin{array}{l}\text { Corton } \\
\text { macrostachyus }\end{array}$ & Bsana & Stem & Giardiasis & $\begin{array}{l}\text { Leaves are chopped and pounded, } \\
\text { and taken orally }\end{array}$ & \\
\cline { 4 - 6 } & leaves & & & &
\end{tabular}

\subsection{Illness Identifications and Therapeutic Methods}

Diseases and illnesses of naturalistic and personalistic etiologies are widely treated by herbalists in the study area. The legally registered herbal medicine practitioners have erected an advertising board (billboard) at the major roadside of the town or attaching to their residence. The billboard contains name, address (including phone number) and major ailments to be treated. The ailments are registered by district health office while obtaining their license. One herbalist honestly told us that although he listed the major diseases he treated on the billboard, he provides treatments for any type of ailments. A significant number of maladies are healed by traditional medicine. In the study area, evil eye, evil spirit, impotency, diabetes, epilepsy, enema, rheumatic fever, rheumatisms, wart, bone fractures and joint dislocation, blood pressure, and hemorrhoids are some of the ailments/illnesses for which traditional healers are highly demanded. Herbal healers are well known by the local community for their effective treatment of these ailments.

\subsubsection{Illness Identifications}

Herbal healers follow a different approach from modern medicine in the identification of health maladies and diagnosis of the patient. Others identify illnesses using the same procedure like modern medicine. Healers are often very close to the patient encouraging them to feel free and modest. The healers take much time in empowering the patient to have a say on the causation and treatment approach. At the outset of the diagnosis process, the healer warmly greets and introduces himself to the patient. The healer then records the name, sex, age, address, mobile number, and the symptom explained by the patient. Although most of the healers are disorganized in keeping the records of their patients' history and even some are very vigilant in keeping the profile of their patients. The illness is identified through intensive discussion with the patients or observing the diseased part of the patients. No modern medical instruments are used to identify the disease. The patients also freely express their health problems pointing finger to the diseased parts of their body. Among indigenous healers who took part in the current study, one herbalist has a stretcher in his clinic for diagnosis. Sometimes the healers gain a better understanding on the history of the disease and its associated symptoms by interviewing a person who accompanies the patients. However, as noted above, for confirmation of certain diseases like HIV, hypertension, diabetes, they direct the patient to modern medicine.

Sometimes diagnosis is made through spiritual means and a treatment is prescribed usually consisting of herbal remedies that are considered to have not only healing abilities but also symbolic and spiritual significance. The healers undergo diagnosis by identifying diseases and causes of illness by employing "explanatory models" asking the patient questions on when the disease began and what the associated symptoms, course of the disease (what the disease does to the body) are, which culminate with appropriate treatments. It consists of the ideas, the episode of illness and its treatment that are employed by all those engaged in the clinical process. Here, the patient is not the passive recipient of the treatment. Rather the treatment is based on negotiation between the healer and the patient. Dinos S. ${ }^{[20]}$ indicated that explanatory model is a kind of approach that shows how patients and healers interpret maladies. In this case, the development of this model helps to identify and decide on the possible therapies undertaken. Actually, explanatory models may not be explicit, but they still are useful in formulating different clinical realities, identifying misinformation and developing awareness among participants. 
Under certain circumstances, due to the sheer number of visitors, the diagnosis process is not based on the negotiation between the patient and the healer. The patient is simply passive, not an active participant in the diagnosis process. The healer does not empower the patient to have a say in the treatment and diagnosis. This herbalist place glassy materials on different parts of the patient's body, and gazes at the glass and then tells the disease to the patient and finally gives the medicine. According to an herbalist whose clinic observed by the researchers, more than 100 patients get treated per day coming from distant areas of the region and beyond. The fame and recognition were largely attributed to his healing power. Patients also spread the healing and curing power of the healer into their village. So as to build confidence on the part of the patient, all healers make use of placebo effect explaining the quality and efficacy of the medicinal drug prescribed.

\subsubsection{Therapeutic Methods/Treatment Processes}

Herbalists inform patients the disease and appropriate treatments: how it should be taken including the dosage; for how long the medicine should be taken and how many times a day; the side effects of the disease and the contraindication (associated action the patient should take). In the visited traditional clinics, no practice of witchcraft and sorcery activities were observed like spell writing, incense burning, and bowing down for the healer. Non-religious rituals are largely used in the treatment process. Occasionally, rather than treating the patient with medicine, they strongly recommend the patient to concentrate on taking balanced diet. In the case of hemorrhoid, fatty and fiber rich foods are the uncommon dietary recommendation. For the same disease, some herbalists prohibited tela (homemade beer) for 6 months. Besides, the patient is warned to avoid sitting or standing under shadow. White teff in the form of injera (traditional Ethiopian food) or bread and chickpea wot (stew) were some of the diet recommendation heard on the scene, and these diets are presumed to increase the volume of the blood that is lost through bleeding. In addition, the patient was advised to wash the diseased area regularly with cold water or tap ice on the diseased part. Moreover, the researcher has come across many herbalists, who forbade their clients not to take alcoholic drinks. It is likely that herbal medicines have side effects. To avoid the possible adverse reaction, herbalists highly recommend milk and milk related products. Although variations exist from practitioners to practitioners, most herbalists' advice their patients to abstain from sexual intercourse while taking the medicinal drugs because it lessens or undermines the healing power of the drug.

\subsection{Why local people prefer Herbalists vis a vis Modern Health Professionals?}

The researcher encountered different categories of individuals in the healers' clinics or resident houses. Some come for their own health problems; some bring their children while others were there on behalf of sick friends or relatives. Most of them visit the healers after exhaustively trying the modern medical system. Others appear believing that indigenous medicine is appropriate for the kind of diseases that gripped them. According to indigenous medicine users and healers, indigenous medicines are very advantageous to cure some diseases like hemorrhoid, "bird disease" (hepatitis), rabies, dermatological diseases and others. The followings are factors that determine the use of indigenous medicine over modern medicine:

Cost effectiveness: Many herbal medicine payments (fees) are more or less cheap. For example, when a person infected with hemorrhoid comes to herbal healers, the payment for the service is not more than $\$ 19$. But, in modern health service, the patient may have to spend more than $\$ 37$ for surgical operation, which may not be affordable to many. So, prohibitive medical costs of the modern medicine makes impossible for the poor to get modern medical attention. Sometimes patients are opting for indigenous healers who do not sometimes demand cash up front like modern medicine. Herbalists also provide health care services moving to patient's home traveling many kilometers. The herbalists complained that some of the patients do not give all the payments after the hemorrhoids are removed.

Easy accessibility: Herbal healers are easily accessible to users who come from rural areas. As the researchers observed, patients were given an appropriate treatment within the user's house or healer's clinic. The users easily access healers without any bureaucratic hurdles or without being limited by rules and regulations, time wastage for lab hours, hotel rent and so on. They can also easily get healers around the 
communities. However, in modern medical services it is very complicated to have access to medical professionals and services. Unlike indigenous medicine, modern medicines are largely limited to urban areas. The latter does not also render treatments at the house of patients.

Cultural acceptability: In the society there is also widely held belief that modern medicine has no solution to health problems of psychological origin or "culture bound syndromes" like ganen (devil) and evil spirit possession except wasting time, energy and money. In the society such kinds of health problems are not referred to the modern health care; rather they are directed to indigenous healers. Furthermore, the patient and healer can easily understand each other with no communication barrier in the diagnosis process. In Debre Markos and the surrounding areas, since time immemorial, indigenous healers have been considered as church scholars with magico-religious education. They are regarded as God fearing and God selected people who have the power of healing and on whom God bestowed the knowledge. In the study area, there has also been a tendency of connecting ailments with wraths of God or supernatural being and some other evil spirits. Therefore, they believe that such evil spirits are exorcised by these personalities.

Dissatisfaction with the modern medicine: Most of the indigenous medicine users who appeared in the indigenous health clinics had visited modern medicine but had not seen any significant improvement other than taking injection and medicinal drugs. They are also disappointed with spending money for laboratory tests and buying prescribed drugs thereby making themselves reportedly vulnerable to gastritis, kidney failures and other health complications. In addition, they argued that allopathic practitioners are not comfortable and compassionate. Similarly, Audet C. et.al [21] indicated that even if allopathic practitioners did not support it, patients in sub Saharan Africa often prefer alternative treatments, traditional medicine. The reason behind is patients perceived that traditional healers are more compassionate than modern practitioners.

\subsection{Challenges for the Development of Indigenous Medicine (Herbalists)}

Based on the data gathered from various stakeholders, the researcher of the current study summarized the various factors that are putting the progress and the very existence of indigenous healers at stake.

The proliferation of illicit healers or quacks: these healers are tarnishing the image of the indigenous medicine and are also eroding the trust of the public on the efficacy of the indigenous medicine. There are also frequent reports of either permanent injuries or deaths from the society. Informant from Debre Markos illustrates "One patient came to my resident place and explained that he has paid \$278 for hemorrhoid. However, he has not seen any significant improvement of his health problem, and he has requested me to negotiate with the healer to pay him back the money or he was vowing to kill him."

Likewise, health officers from the region's health bureau also supported this idea expressing that there are death reports and frequent injuries that force the regional heath bureau to endorse proclamation and regulation on how to guide, coordinate, administer and license indigenous medical practitioners. Herbalists stated that there is no cooperation from government security forces on making the illegally functioning healers accountable. This is also discouraging the legally functioning herbalists. One informant states "We are paying a huge amount of tax per year. But illegal practitioners are illegally exploiting the society without paying taxes. I am also planning to become illegal practitioners; even if we are licensed, we are not receiving any support from the government." The health officers of the region and the town also agree with this notion. They admitted their reluctance in working with the security apparatus of their respective area in stopping the illegally functioning healers.

Over exploitation and related environmental problems: if the medicinal plants disappear, the indigenous medicine would also disappear. The indigenous medical practitioners highly depend on medicinal plants. So, plants that are proved to have medicinal value through research should be cultivated, registered and documented. Since the plants are arsenal of medicine, plants whose roots are being used are on the verge of vanishing due to the absence of substitute to plant these trees. The expansions of agricultural activities, excessive clearance of the natural vegetation for different purposes, over exploitation of medicinal plants by practitioners and lack of support from concerned bodies are some of the major threats of herbal 
medicines in the area under study. Even though healers frequently requested the government for botanical garden, there has not been positive response yet. Appiah S. et.al [22] illustrated the experience of Southern Ghana by which in the previous time medicinal plants was abundant in the natural vegetation. However, now a day because of the expansion of agricultural activities followed by excessive harvesting and clearance of the natural vegetation are the major threat to the existence of medicinal plants.

The dominance of biomedicine: the dominant position of biomedicine and the subsequent insults from modern professional workers are also worth mentioning challenges. Lack of recognition from the government for their knowledge especially protection of intellectual property is also another factor. Moreover, there is no enough and large-scale training for healers on health care delivery. Inhibitions to provide primary or basic medical care to their patients and other medical instruments have also an adverse effect on their health care service. There is a lot of tension between biomedical workers and indigenous healers over the usefulness of indigenous healing. There is also absence of strict follow up and supervision from regional health bureau, zonal and district health office on the practice of the indigenous healers. One informant explained "Before five years I used to practice indigenous medicine in Addis Ababa around Bole Michael area, the health experts of the sub-city had been visiting us regularly with an interval of three days. Here [in Debre Markos] local government authorities and biomedical workers are not considering us as health care provider rather we are considered to be detrimental to the health of the society." Above all the past policies and proclamations paved the way for the dominance of biomedicine and made indigenous medicine to have a subordinated position.

Inheritance problems: the offspring (sons and daughters) of herbalists are not willing to inherit the knowledge considering the practice as a primitive or manifestation of backwardness. For instance, one informant's daughter mentions "I do not want to inherit the herbal medicinal knowledge because it is backward and outdated practice." Likewise, Karah E. et.al [23] indicated similar challenge in Ghana that youths are not interested to inherit knowledge related to traditional healing since mastering it requires long period of apprenticeship and it lacks status and attractiveness. As a result, most youths prefer to join modern education.

Absence of support from concerned authorities: the health bureau of the region disallows indigenous healers to use medical instruments and prescribe modern drugs. However, most of the healers use gloves, bandage, alcohol, scissors and petroleum jelly. The illegal practitioners use even injection and many other drugs illegally. This makes the integration of the two medical systems far from being realized in the near future.

Interestingly, the regional indigenous medicine association aspires to establish college of indigenous medicine in which Ethiopian young generation could learn traditions, culture and knowledge of indigenous medicine. They express that this is important for the persistence and transference of the medical knowledge for the generation in an organized manner. One informant describes "We have tried our best to exert influence on the government to restore the power of registering and licensing healers to the region's healers association, but that ends in vain." Previously, the regional association was given responsibility to provide license for indigenous healers, later on because of successive complaints and corruptions; the association was disempowered from the duty. Thus, the regional health bureau and its structure have taken the responsibility. According to informants, the association is powerless and in effectual.

The concerned government bodies do not also provide assistance and take legal measure in accordance with the proclamation. Therefore, the indigenous medicines in the study area are poorly regulated. There is also a lack of detailed documentation of the indigenous knowledge which is largely transferred orally from generation to generation.

\section{Conclusion}

Ethiopia has a long tradition of promoting health and treating health disorders. Herbal therapy has been practiced since time immemorial and still today a great majority of the population is using herbal treatment. Herbalists are highly dependent on plant products like leaves, barks, stems, roots, flowers, fruits and seeds. 
In addition, herbalists are well aware of the locality of the medicinal plants and the ritual procedures to be followed. Medicinal Plants are consumed by customers, through the order of the healers, in the form of flour, liquid, ointment or raw form and most of the time mixed with honey, butter and holy water. This research can provide information or add knowledge on the operations of indigenous medicine in Debra Markos town and document their contribution in providing health care delivery to the community. It also helps health policy planners to recognize the contribution of indigenous healers in the health care system thereby improving the health care system of the larger society. However, plants which are arsenal of medicine have been diminished from time to time. So, in order to protect medicinal plants from extinction, concerned government authorities need to encourage and support healers to grow medicinal plants. To this end, botanical gardens have to be prepared and given for healers. Modern medical professionals, universities and herbalists should work in collaboration to conduct rigorous researches for documentation of medicinal plants. Further researches have to be conducted to ascertain the healing or curing power of the plants used, since the healing power of most plants has not been explored yet. Moreover, universities should cooperate and assist healers in the preparation, prescription, preservation and administration of medicinal plants. In order to mitigate illegal practitioners and protect the mass from serious health hazards that are happening, effective governmental task force should be formed to facilitate the registration and licensing of all indigenous healers.

\section{Declarations}

\subsection{Study Limitations}

Shortage of fund, latest literatures, information because of secrecy of the issue and time are some of the major limitations that this work faced.

\subsection{Participant's Consent}

We the authors can assure you that appropriate informed consent and permissions are taken from informants and participants of this work before and in the process of the research.

\subsection{Competing Interests}

We the authors declare that there is no competing interest against this research article. There is no financial, non-financial, professional and personal conflict in relation to it and we can take full responsibility for the originality of the work.

\section{How to Cite this Article:}

Taha, E., \& Woldeyohannes, M. (2019). Herbalists and their Mode of Health Care Service Delivery in Debre Markos Town, Northwest Ethiopia. Advanced Journal of Social Science, 6(1), 122-137. doi:10.21467/ajss.6.1.122-137

\section{References}

[1] Mirzaeian R. 2019. Progresses and challenges in the Traditional Medicine Information System: A Systematic Review. Journal of Pharmacy and Pharmacognosy Research, 7(4), 246-259.

[2] Tuasha N. 2018. Medical Plants Used by Traditional Healers to Treat Malignancy and other Human Ailments in Dalle District, Sidama Zone, Ethiopia. Journal of ethnobiology and Ethnomedicine (2018) 14:15.

[3] Wolditsadik A. 2019. Traditional Medicinal Plants in Ethiopia. International Journal of biology Physics and Mathematics. Volume 1, Issue 1, 2019. PP 80-87.

[4] Letebo A. 2018. Ethnobotanical Survey of Common Medicinal Plants Used by Alefo kebele, Amaro Wereda Area, Southern Ethiopia. The Pharmaceutical and Chemical Journal; 5(2):100-109.

[5] Tewodros A and Worku W. 2018. Ethno Botanical Study of Indigenous Knowledge on Plants to Treat Diseases in some selected Districts of Amhara National Regional state, Ethiopia. Ethiopia. Journal of Medicinal Plants Research, Vol. 12(29), pp. 528-536.

[6] Yebirzaf Y., Esubalew T and Worknesh T. 2019. The Dynamics of Medicinal Plants Utilization Practice Nexus its Health and Economic Role in Ethiopia: A Review Paper. International Journal of biodiversity and conservation. Vol. 11(1), pp. 31-47.

[7] Masresha M. 2019. Knowledge and Use of Medicinal Traditional Plant Species Ailments in Haramaya, Ethiopia. International Journal of Environmental Chemistry. Vol. 3, No. 1, pp. 18-23.

[8] Dugassa D. et.al. 2018. Ethno Medical Survey Among the Residents of Nekemtie Town, East Wollega Zone, Oromia National Regional State, Ethiopia. International Journal of Modern Pharmaceutical Research. IJMPR2018, 2(4), 22-37. 
Herbalists and their Mode of Health Care Service Delivery in Debre Markos Town, Northwest Ethiopia

[9] Andarge A.2017. Monitoring the Urban Growth of Debre Markos Town (1984-2012), Ethiopia: Using satellite Images and GPS. Journal of Geography and Regional Planning. 10(4):69-76.

[10] Abebaw M. and Akola J. 2016. Environmental Perspective of Urban Agriculture in Debre Markos Town, Amhara Regional State, Ethiopia. British Journal of Environmental Sciences. 4(2):24-36.

[11] Mekuriaw T. and Gokcekus H. 2019. The Impact of Urban Expansion on Physical Environment in Debre Markos Town, Ethiopia. Vol.11, No.5.

[12] Edwards S, Tadesse M, Demissew S, Hedberg I (eds) (2000). "Flora of Ethiopia and Eritrea". Volume 2, part 1. Magnoliaceae to Flacourtiaceae. The National Herbarium, Addis Ababa, Ethiopia. Department of Systematic Botany; Uppsala, Sweden. ISBN 97891-971285-2-0.

[13] Tadesse M. Ethno botany in Ethiopia. 2008. Encyclopedia of the History, Science, Technology and Medicine in Non-Western Cultures. Ed. Selin H.

[14] Hedberg I, Edwards S, Sileshi N . "Flora of Ethiopia and Eritrea". 2003. Volume 4, Part 1. Apiaceae to Dipsaceae. The National Herbarium, Addis Ababa, Ethiopia, and Department of Systematic Botany, Uppsala, Sweden. ISBN: 9789197128551.

[15] Yemane B. et.al. 2017. Survey of Some Common Medicinal Plants Used in Eritrean Folk Medicine. American Journal of Ethno medicine.

[16] Firew B. 2019. Ethnobotanical Studies of Medicinal Plants used to Treat Human and Livestock Ailments in Southern Nations, Nationalities and Peoples' Region, Ethiopia: A Systematic Review Journal of Plant Studies; Vol. 8, No. 1.

[17] Tlahun T. and Moa M. 2018. Ethno botanical Study of Medical Plants Used to Treat Human Diseases in Berber District, Bale Zone of Oromia Regional State, South East Ethiopia. Evidence-Based Complementary and Alternative Medicine.

[18] Boadu A. and Asase A. 2017. Documentation of Herbal Medicines Used for the Treatment and Management of Human Diseases by Some Communities in Southern Ghana. Evidence-Based Complementary and Alternative Medicines.

[19] Jyoti P. et.al. 2018. Herbs as a Traditional Medicine. Journal of Drug Delivery and Therapeutics. (5): 146-150.

[20] Dinos S. et.al. 2018. Assessing Explanatory Models and Health Beliefs: An Essential but Overlooked Competency for Clinicians. Cambridge University Press.

[21] Audet C. Traditional Healer Treatment of HIV Persists in the Era of ART: A Mixed Methods Study from rural South Africa. BMC Complementary and Alternative Medicine. Article number: 434.

[22] Appiah S. et.al. 2018. Medicinal Plants Used in the Ejisu- Juaben Municipality, Southern Ghana: An Ethno Botanical Study. Medicines 2019, 6, 1.

[23] Karah E. 2018. Integrating Traditional Healers into the Health Care System: Challenges and Opportunities in Rural Northern Ghana. Journal of Community Health; 43(1): 157-163.

Publish your research article in AIJR journals-

Online Submission and Tracking

Peer-Reviewed

Rapid decision

Immediate Publication after acceptance

Articles freely available online

Retain full copyright of your article.

Submit your article at journals.aijr.in
Publish your books with AIJR publisher-

$\checkmark$ Publish with ISBN and DOI.

$\checkmark$ Publish Thesis/Dissertation as Monograph

$\checkmark$ Publish Book Monograph.

$\checkmark$ Publish Edited Volume/ Book.

$\checkmark$ Publish Conference Proceedings

$\checkmark \quad$ Retain full copyright of your books.

Submit your manuscript at books.aijr.org 